\title{
What Is The New and Sensitive Tumor Marker for Detection of Different Kidney Tumors? Modern Study to Isolation, Purification and Characterization of N-Acetyl Galactosamine Binding Lectin From Sera Of Patients With Kidney Cancer
}

\author{
Dr. Rasha Hasan Jasim*, Dr. Hathama Razooki Hasan**, Dr. Majed Khadum Husain*** \\ * Chemistry Department, College of Education for Girls, University of Kufa \\ e-mail:dr.rashahussainee@yahoo.com \\ ${ }^{* *}$ Chemistry Department, College of Science, University of Baghdad \\ e-mail:hathama2009@yahoo.com

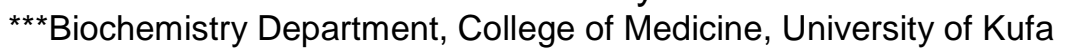 \\ e-mail:majidkhadum@yahoo.com
}

\begin{abstract}
The present study was designed to investigate lectins in sera of patients with kidney tumors, in addition to non tumoral kidney disease patients. Fifty five patients of malignant kidney tumors were enrolled in addition to 23 patients of benign kidney tumors, and 18 patients of non tumoral kidney diseases used as control groups, in addition to 46 healthy individuals were also investigated. The age of patients and healthy individuals were 10-90 years. The measurement of total serum proteins revealed significant $(p<0.001)$ decrease in patients of malignant tumors when compared with those of benign, non tumoral diseases, and healthy individuals. The conditions of the hemagglutination assay of serum lectin activity were optimized. They were Tris buffer of $20 \mathrm{mM}$ and $\mathrm{pH} 7.4,60 \mathrm{mM} \mathrm{CaCl}_{2}, 800 \mu \mathrm{g}$ of defatted serum, $30{ }^{\circ} \mathrm{C}$ for serum samples, 60 minutes for serum samples, and human blood of group $A^{+}$suspension with 1.4 optical density. The measurement of the specific hemagglutination activity of lectins demonstrated significant $(p<0.001)$ elevation in patients of malignant tumors when compared with those of other patients and healthy individuals. Lectin activity was pointed out to be significantly $(r=$ 0.767 at $p<0.0005)$ positively correlated with stage of malignancies. The cutoff value of the specific hemagglutination activity was found to equal $6 \mathrm{SHU}$ for discriminatory malignant kidney tumors. Serum lectins activity were indicated to be inhibited by galactose, mannose, lactose, and $\mathrm{N}$-acetyl galactosamine. Purification of lectin from sera of patients with malignant kidney tumors by affinity chromatography with the use of silver stain revealed N-Acetyl Galactosamine Binding Lectin (GalNAcBL). The purified folds and the yield was 178 with $32.4 \%$. The polyacrylamide gel electrophoresis (PAGE) of purified lectin demonstrated one band consisted lectin activity. The approximate molecular weight of GalNAcBL was determined and found to be 63.83. Purified lectin was characterized through the assessment of the capability to agglutinate RBCs, inhibition by EDTA, pH dependency, thermal dependent, and carbohydrate contents. GalNAcBL were observed to be calcium dependence lectins (C-type). These results suggest that the diagnosis of the specific hemagglutination activity of lectin is promising biomarker for discrimination of malignant kidney tumor patients and the purified lectin could be introduced in the field of biomarkers.
\end{abstract}

Key Words: Lectin, Kidney, Cancer, N-Acetyl Galactosamine Binding Lectin, Tumor, Purification

\section{Council for Innovative Research}

Peer Review Research Publishing System

Journal: Journal of Advances in Chemistry

Vol. 4, No. 2
editor@cirworld.com

www.cirworld.com, member.cirworld.com 


\section{Introduction}

Lectins are ubiquitous proteins or glycoproteins that are present in all eukaryotic cells [1-6], and many bacterial species [7, $8]$, as well as in some viruses [9, 10]. They are capable to bind mono- and oligosaccharides with high affinity [11, 12], and usually agglutinate cells or precipitate polysaccharides and glycoconjugates specifically and reversibly [13, 11]. The binding involves hydrophobic interactions as well as hydrogen bonds [14]. Lectin specificity for individual sugars or groups of sugars makes them powerful tools for detecting changes in the carbohydrate structure of the glycoproteins [15, 16]. Several lectins are investigated for their use in cancer research and therapy. Preliminary findings suggest that some lectins can detect alterations of malignant cells as well as reduce the cancer cell tumorigenicity and thus may be helpful for prognosis of the immune status of the patients [17].

Glycoproteins are built up in a sequential step-by-step process in the Golgi apparatus, starting with the addition of $\mathrm{N}$-acetyl galactosamine to serine or threonine residues. Subsequently, elongation of O-linked sugars is achieved by transfer of additional sugar residues to the already glycosylated protein [18]. These reactions are catalyzed by different glycosyltransferases whose specificities, sequential action, relative activity levels, and intracellular localization determine a cell-specific O-glycosylation profile. The initial key step in the regulation of O-glycosylation is the transfer of $\mathrm{N}$-acetyl galactosamine from UDP- N-acetyl galactosamine to Ser or Thr residues on an acceptor polypeptide. This reaction is catalyzed by a family of UDP- $\mathrm{N}$-acetyl galactosamine polypeptide $\mathrm{N}$-acetylgalactosaminyl transferases (ppGalNAc-Ts). One mechanism for glycoprotein glycosylation changes in cancer cells could be a differential expression of ppGalNAc-Ts. Functional profiles of each component of the family have been characterized showing that these enzymes not only have different substrate specificities but also specific tissue-expression patterns [19-21]. Several studies [20, 22-28], attributed malignancy to the stimulation of ppGaINAc-T2 or ppGalNAc-T3 in malignant tumor cells, in which different expression patterns of these enzyme have been described. Present study designed to investigate the kidney cancer effect in activation of glycosylation reaction through purification and evaluate $\mathrm{N}$-acetyl galactosamine binding lectin as a product to stimulation of enzymes of this pathway.

\section{Subjects, Materials, and Methods}

Patient and Control Individuals: The present study involved 96 patients ( 55 cases with malignant kidney tumors, 23 cases with benign kidney tumors, and 18 cases with non tumoral kidney diseases) with the age range 10-80 years, in addition to 46 healthy individuals, at the same age range.

Isolation of Crude Lectins from Serum Specimens: Ten milliliters of venous blood samples were collected from patients and the control groups. Samples were allowed to clot at room temperature, centrifuged at $3000 \mathrm{xg}$ for 5 minutes, and then sera were collected and stored at $-15^{\circ} \mathrm{C}$. For isolation of serum crude lectins, 1 volume of serum was mixed with 2.5 volumes of petroleum ether for defatting. The mixtures were shacked strongly, then, centrifuged at $3000 \times \mathrm{xg}$ for 5 minutes. The organic phase was neglected and defatted serum was stored at $-15^{\circ} \mathrm{C}$ to be used for determination of the hemagglutination activity.

Preparation of Standard Ttrypsinized Erythrocyte Suspension for Hemagglutination Test: Human blood group $\mathrm{O}^{+}$erythrocytes were collected from the local blood bank in Al-Sadder Teaching Hospital in Najaf in Iraq. Blood was centrifuged at $3000 \mathrm{xg}$ for 5 minutes, the sera were discarded. The erythrocytes were washed with saline solution (5 ml saline: $1 \mathrm{ml}$ packed erythrocytes),then were suspended in phosphate buffer saline solution ( $\mathrm{pH} 7.4)$, and diluted with the same buffer to give an absorbance of $2 \mathrm{ml}$ at $620 \mathrm{~nm}$. One part of trypsin solution (1\%) was added to 10 parts of the final erythrocytes suspension. The mixture was incubated at $37^{\circ} \mathrm{C}$ for 1 hour, and then centrifuged at $5000 \mathrm{xg}$ for 5 minutes. The trypsinized erythrocytes mixture was washed $3-5$ times with saline solution to remove trypsin traces. Saline solution was added, until the absorbance of the erythrocyte suspension was 1.4 at $620 \mathrm{~nm}$.

Protein Determination: Total proteins in the studied samples were estimated using Bradford method [29],and bovine serum albumin was used as a standard protein.

Determination of Hemagglutination Activity of Crude Serum Lectins of Patient and Control Groups: To determine the hemagglutination activity in serum Lis and Sharon [30] method was used, with essential modifications. The procedure involved three tubes, test $(T)$, blank $(B)$, and control $(C)$. A set of control tubes $(2-4)$ were used in each experiment and the assay was carried out as in the following: 


\begin{tabular}{|c|c|c|c|}
\hline Components & Test & Blank & Control \\
\hline 1) Diluted serum (1:20) with Tris- $\mathrm{HCl}$ buffer (20 Mm, $\mathrm{pH} 8)$ & $1 \mathrm{ml}$ & $1 \mathrm{ml}$ & - \\
\hline 2) Trypsinized erythrocyte suspension. & $2 \mathrm{ml}$ & - & $2 \mathrm{ml}$ \\
\hline 3) Saline solution. & - & $2 \mathrm{ml}$ & $1 \mathrm{ml}$ \\
\hline 4) Calcium chloride solution (60 mM). & $1 \mathrm{ml}$ & $1 \mathrm{ml}$ & $1 \mathrm{ml}$ \\
\hline \multicolumn{4}{|c|}{$\mathrm{T}, \mathrm{B}$, and $\mathrm{C}$ tubes were placed in exactly vertical position at $37^{\circ} \mathrm{C}$ for $75 \mathrm{~min}$. } \\
\hline \multicolumn{4}{|c|}{$\begin{array}{l}\text { Cells were separated after centrifugation at } 3000 \mathrm{xg} \text { for } 3 \text { minutes, then re-suspended in the above } \\
\text { mentioned buffer by gentle shaking, and allowed to stand for another } 75 \text { minutes at } 37^{\circ} \mathrm{C} \text {. }\end{array}$} \\
\hline
\end{tabular}

The reduction of optical density (ROD) in the test tube (in crude sera determination) was measured from the following equation:

Where:

${ }_{C}$ : Optical density of cell suspension in the control tube.

$A_{T-B}$ : Optical density of cell suspension in the test tube - Optical density of cell suspension in the blank tube.

Purification of GaINAcBL: Affinity chromatography technique was applied for the purification of GalNAcBL from patients with malignant kidney tumors. Preparation of the affinity chromatography column was carried out according to the instructions of Hermanson [31], and Amersham handbook [Amersham Pharmacia Biotech].

Determination of Carbohydrate Content in the Purified GalNAcBL: Dubois method [32] was followed for determination of carbohydrate amount in the purified GalNAcBL. Where glucose was used as a standard sugar.

\section{Results and Discussion}

Levels Of The Serum Specific Hemagglutination Activity In Patients and Control Groups: The optimized conditions of the hemagglutination protocol were used for estimation of individual serum lectin activity in the studied groups. It was expressed as specific hemagglutination activity unit (SHU). Figure 1 demonstrates that 52 patients out of the 55 studied patients of malignant kidney tumors have a hemagglutination activity higher than 6 SHU, while those of non tumoral kidney diseases and healthy individuals (except one sample in each group) have less than $6 \mathrm{SHU}$. Also those of benign kidney tumors were found to have specific activity less than 6 SHU. These results suggest the possibility of using 6 $\mathrm{SHU}$ as a cutoff value for the specific hemagglutination activity. A result showed the possibility of using this parameter as a biomarker for discriminating of patients with malignant kidney tumors among those with benign, non tumoral kidney diseases, and healthy individuals.

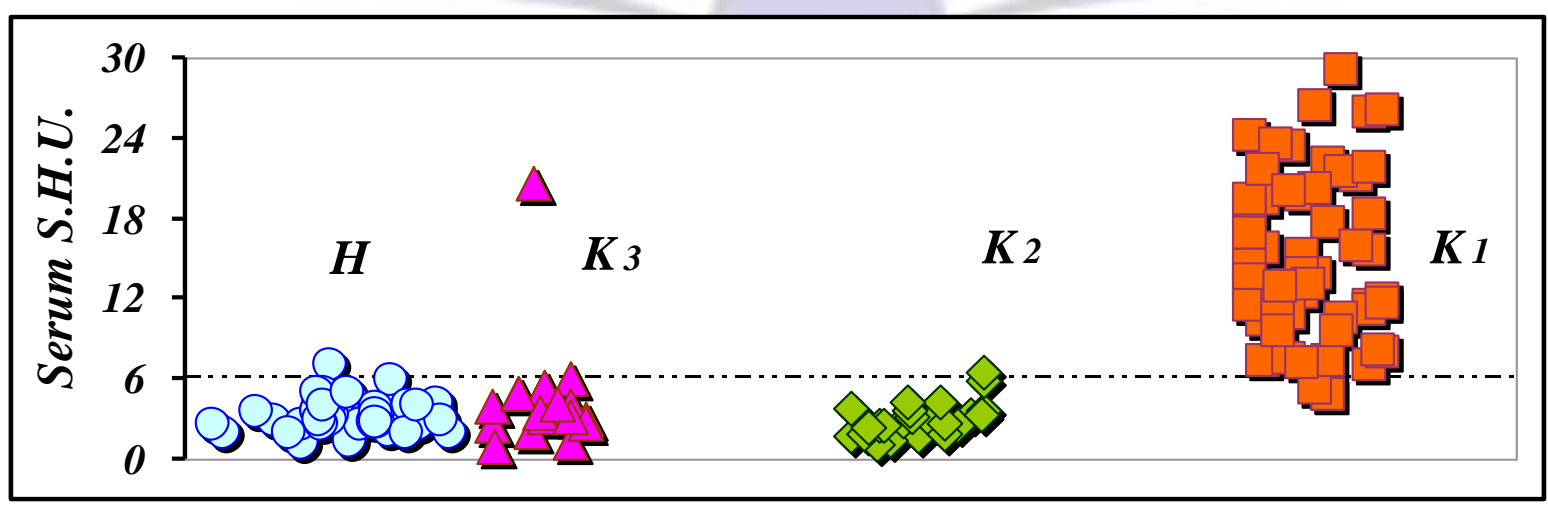

Fig 1: Distribution of the Serum Hemagglutination Activity in Patients of Malignant Kidney Tumors $\left(\mathrm{K}_{1}\right)$, Benign Kidney Tumors $\left(\mathrm{K}_{2}\right)$, Non Tumoral Kidney Diseases $\left(\mathrm{K}_{3}\right)$, and Healthy Individuals $(\mathrm{H})$. The symbol - - - refer to the cutoff of malignant kidney tumors value 
The evaluation of the specific hemagglutination activity in the various groups revealed a significant increase $(p<0.001)$ in patients of malignant kidney tumors when compared with those of benign tumors, non tumoral kidney diseases, and healthy individuals. However, non significant variations were obtained when other groups were compared together (Table 1). The sensitivity and specificity of serum lectin activity in detection of malignant kidney tumors were $94.54 \%$ and 95.65 $\%$ respectively.

Table 1: Serum Specific Hemagglutination Activity Levels in Patients of Malignant Kidney $\left(\mathrm{K}_{1}\right)$ and Benign Kidney $\left(\mathrm{K}_{2}\right)$ Tumors, Non Tumoral Kidney Diseases $\left(\mathrm{K}_{3}\right)$, and Healthy Individuals $\left(\mathrm{HK}_{1}\right.$ and $\left.\mathrm{HK}_{2}\right)$

\begin{tabular}{|c|c|c|c|c|}
\hline Groups & $\begin{array}{l}\text { Age (year) } \\
\text { Mean } \pm \text { S.D. } \\
\text { Range }\end{array}$ & $\begin{array}{c}\text { SHU } \\
\text { Mean } \pm \text { S.D. }\end{array}$ & Range & $p$ \\
\hline $\begin{array}{c}K_{1} \\
(55)\end{array}$ & $\begin{array}{c}54.93 \pm 12.50 \\
32-80\end{array}$ & $14.99 \pm 6.21$ & $4.79-29.08$ & $0.000^{\star *}$ for $K_{1}$ vs $K_{2}$ \\
\hline $\begin{array}{c}\mathrm{K}_{2} \\
(23)\end{array}$ & $\begin{array}{c}45.04 \pm 15.33 \\
10-66\end{array}$ & $3.04 \pm 1.31$ & $1.17-6.49$ & $0.000^{* *}$ for $K_{1}$ vs $K_{3}$ \\
\hline $\begin{array}{l}K_{3} \\
(18)\end{array}$ & $\begin{array}{c}42.39 \pm 16.60 \\
12-68\end{array}$ & $4.44 \pm 4.27$ & $0.99-20.70$ & 0.309 for $K_{2}$ vs $K_{3}$ \\
\hline $\begin{array}{l}\mathrm{H}_{\mathrm{K} 1} \\
(32)\end{array}$ & $\begin{array}{c}47.38 \pm 10.92 \\
32-80\end{array}$ & $4.27 \pm 1.87$ & $1.09-9.09$ & $0.000^{\star *}$ for $K_{1} v H_{K 1}$ \\
\hline $\begin{array}{l}\mathrm{H}_{\mathrm{K} 2} \\
(43)\end{array}$ & $\begin{array}{c}39.77 \pm 13.77 \\
10-66\end{array}$ & $3.94 \pm 1.71$ & $1.09-9.09$ & $\begin{array}{l}0.491 \text { for } \mathrm{K}_{2} \text { vs } \mathrm{H}_{\mathrm{K} 2} \\
0.724 \text { for } \mathrm{K}_{3} \text { vs } \mathrm{H}_{\mathrm{K} 2}\end{array}$ \\
\hline
\end{tabular}

In the present study, the hemagglutination activity levels in 21 patients with malignant kidney tumors were followed up for 72 hours after surgical operation, of the removal of the tumor. the result showed presence of a decrease in their serum hemagglutination activities after the removal of the tumors (data not shown).

Implication of Stages of Malignancy in Serum and Tissue Specific Hemagglutination Activity: In order to verify the changes of the hemagglutination activity with the advancing of malignancy, the patients were subdivided according to the stage of the diseases into stage I, II, III, and IV. From the statistical analysis of the malignant kidney tumors of different stages, a positive correlation was observed between the serum specific hemagglutination activity \& the malignant tumor progression $(r=0.767$ at $p<0.0005)$ (Figure 2).

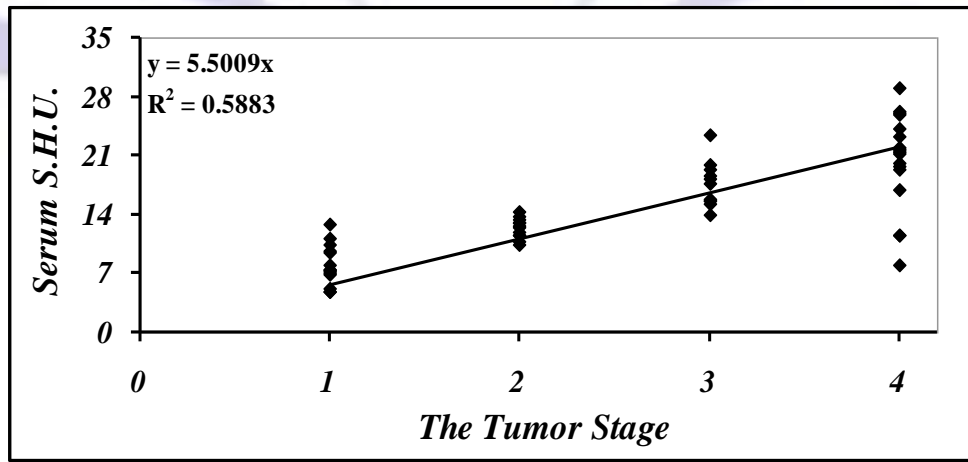

Fig 2: Correlation of Serum Hemagglutination Activity with Stages of Malignant Kidney Tumors

The mean levels of specific hemagglutination activity in patients of the four stages of malignant kidney tumors are illustrated in Table 2. Significant elevations $(p<0.001)$ of the specific hemagglutination activity were observed when the data of each two stages (except III and IV) were compared. 
Table 2: The Differences in Serum Specific Hemagglutination Activity of Malignant Kidney Tumor Patients According to the Stage of the Disease.

\begin{tabular}{|c|c|c|c|c|}
\hline Subjects & $\begin{array}{l}\text { Age (year) } \\
\text { Mean } \pm \text { S.D. } \\
\text { Range }\end{array}$ & $\begin{array}{c}\text { SHU } \\
\text { Mean } \pm \text { S.D. }\end{array}$ & Range & p \\
\hline $\begin{array}{c}\text { Stage I } \\
(14)\end{array}$ & $\begin{array}{c}49.07 \pm 11.94 \\
32-74\end{array}$ & $8.03 \pm 2.40$ & $4.79-12.80$ & \multirow{4}{*}{$\begin{array}{c}0.000^{* *} \text { For }(1,2,3,4, \text { and } 5) \\
0.011 \text { for }(6)\end{array}$} \\
\hline $\begin{array}{c}\text { Stage } \Pi \\
(12)\end{array}$ & $\begin{array}{c}55.67 \pm 13.85 \\
34-79\end{array}$ & $12.40 \pm 1.21$ & $10.37-14.42$ & \\
\hline $\begin{array}{c}\text { Stage Ш } \\
(11)\end{array}$ & $\begin{array}{c}53.73 \pm 9.71 \\
43-75\end{array}$ & $17.58 \pm 2.73$ & $13.87-23.47$ & \\
\hline $\begin{array}{c}\text { Stage IV } \\
(18)\end{array}$ & $\begin{array}{c}59.72 \pm 12.40 \\
41-80\end{array}$ & $20.55 \pm 5.57$ & $7.97-29.08$ & \\
\hline
\end{tabular}
1) Stage I vs. Stage II
2) Stage I vs. Stage III
3) Stage I vs. Stage IV
4) Stage II vs. Stage III
5) Stage II vs. Stage IV
6) Stage III vs. Stage IV

Gender Involvement in Kidney Lectins Hemagglutination Activity Changes: The effect of gender on the kidney specific hemagglutination activity levels in patients of cancerous tumors, benign tumors, and non tumoral kidney subgroups was evaluated. Student's $t$-test failed to exhibit significant changes among male and female patients (Table 3).

Table 3: Gender Differences of Serum Specific Hemagglutination Activity in Tumoral and non Tumoral Kidney Disease Patients and Healthy Individuals.

\begin{tabular}{|c|c|c|c|c|c|}
\hline Type & Gender & $\begin{array}{c}\text { Age (year) } \\
\text { Mean } \pm \text { S.D. } \\
\text { Range }\end{array}$ & $\begin{array}{c}\text { SHU } \\
\text { Mean } \pm \text { S.D. }\end{array}$ & Range & $p$ \\
\hline \multirow{2}{*}{$\begin{array}{c}K_{1} \\
(55)\end{array}$} & $\begin{array}{c}M \\
(36)\end{array}$ & $\begin{array}{c}57.31 \pm 13.69 \\
32-80\end{array}$ & $15.48 \pm 6.94$ & $4.79-29.08$ & \multirow[b]{2}{*}{0.259} \\
\hline & $\begin{array}{c}F \\
(19)\end{array}$ & $\begin{array}{c}50.79 \pm 9.19 \\
37-65\end{array}$ & $14.08 \pm 4.55$ & $7.97-21.69$ & \\
\hline \multirow{2}{*}{$\begin{array}{c}K_{2} \\
(23)\end{array}$} & $\begin{array}{c}M \\
(14)\end{array}$ & $\begin{array}{c}43.93 \pm 16.73 \\
10-66\end{array}$ & $2.40 \pm 0.77$ & $1.17-3.59$ & \multirow[b]{2}{*}{0.377} \\
\hline & $\begin{array}{l}F \\
(9)\end{array}$ & $\begin{array}{c}47.44 \pm 12.28 \\
25-62\end{array}$ & $4.04 \pm 1.38$ & $2.45-6.49$ & \\
\hline \multirow{2}{*}{$\begin{array}{c}\mathrm{K}_{3} \\
(18)\end{array}$} & $\begin{array}{c}M \\
11)(\end{array}$ & $\begin{array}{c}47.36 \pm 11.33 \\
27-62\end{array}$ & $3.95 \pm 1.23$ & $2.05-6.00$ & \multirow[b]{2}{*}{0.550} \\
\hline & $\begin{array}{l}F \\
(7)\end{array}$ & $\begin{array}{c}34.57 \pm 21.22 \\
12-68\end{array}$ & $5.21 \pm 6.92$ & $0.99-20.70$ & \\
\hline
\end{tabular}




\begin{tabular}{|c|c|c|c|c|}
\hline & M & $44.24 \pm 9.57$ & $4.69 \pm 2.08$ & $1.09-9.09$ \\
\hline H & $(21)$ & $10-81$ & & \\
\hline & $F$ & $44.88 \pm 17.10$ & $3.53 \pm 1.14$ & $1.09-6.13$ \\
\hline
\end{tabular}

$\mathrm{K}_{1}$ :Malignant Kidney Tumor Patient group, $\mathrm{K}_{2}$ : Benign Kidney Tumor Patient group, $\mathrm{K}_{3}$ : Non Tumoral Kidney Patients, and $\mathrm{H}$ : total healthy individuals. M: Male, F: Female. The mean difference is significant at 0.001 level

Previously, the source of increased serum lectins in cancer patient was reported to be unclear [33], but these increases may explain through the malignant tumors are the sources of lectin present in the sera of the malignant patients.

Increased levels of lectins in malignant tumor specimens may be due to: (1) during malignancy, an increased expression of oncogene proteins due to chromosomal translocation, amplification, or mutation that is considered one of the main alterations in the cancer cells. Lectin may be one of these proteins. (2) In malignant tumor cells, the loss of tumor suppressor gene protein products due to deletion or mutation, may lead to increase the oncogene proteins, where lectin may be among them. (3) Genetic imprinting errors and genetic instability leading to progressive loss of regulated cell proliferation, increased invasiveness, and increased metastatic potential. Expression of lectins is completely controlled by the machinery system of protein synthesis. Therefore, it is prone for alteration during malignant transformation [4]. (4) The elevation in several carbohydrates concentrations in malignant cells and the aberrant glycosylation of glycoproteins [16] can be considered one of the causes for lectin production.

In the present study, removal of the tumors, decreased serum hemagglutination activity, thus tumor tissues are most likely to produce and secrete lectins in sera. The agglutination test of cancerous tissues showed that lectin was found not only on malignant cells but also in macrophages and stromal cells (mainly fibroblasts) near cancer focus, and the stromal cells immediately adjacent to cancer nests was found to have higher levels of the hemagglutination activity in comparison to cells far from the nests. These results suggest that circulating lectins are generated not only by tumor cells but also from peritumoral inflammatory cells and stromal cells.

Purification of Serum Human GalNAcBL: Hydrophobic Affinity Chromatography was used for isolation and purification of GalNAcBL from sera of patients with malignant kidney tumors. The purification protocol was carried out by using sepharose $6 \mathrm{~B}$ column activated with bis-oxirane $\left(1,4-\right.$ Butanediol diglycidyl ether) $\left(\mathrm{C}_{10} \mathrm{H}_{18} \mathrm{O}_{4}\right)$. The chromatogram of the purified GalNAcBL was demonstrated in Figure 3.

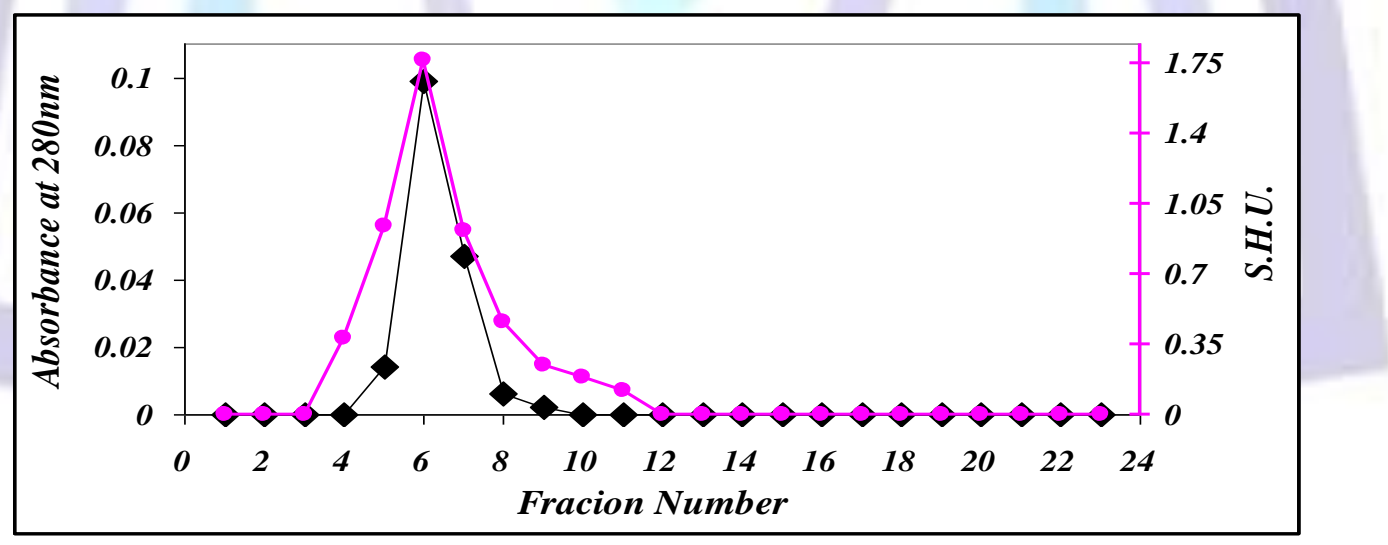

Fig 3: Affinity Chromatogram of Malignant GalNAcBL using Sepharose 6B // N-Acetyl Galactosamine Column $(1.6 \times 1.3)$ at Flow Rate $30 \mathrm{ml} /$ hour. The volume of each fraction was $1 \mathrm{ml}$. Tris Buffer checked $20 \mathrm{mM}$ and 7.4 $\mathrm{pH}$, contained $60 \mathrm{mM} \mathrm{CaCl}_{2}$ was used as a Washing Solution. The Elution step was carried out using a Tris Buffer (20 mM, pH 7.4) contained 10 mM N-Acetyl Galactosamine and 5mM of EDTA. 
The purification folds and the yield of GalNAcBL from malignant kidney tumors were 178 with 32.4.

Table 4: Results of the Purification Protocol of Lectins from Sera of Patients with Malignant Kidney Tumors

\begin{tabular}{|c|c|c|c|c|c|c|}
\hline $\begin{array}{c}\text { Purification } \\
\text { step }\end{array}$ & $\begin{array}{c}\text { Total } \\
\text { volume } \\
\text { (ml) }\end{array}$ & $\begin{array}{l}\text { Total protein } \\
\text { (mg) }\end{array}$ & $\begin{array}{c}\text { Total activity } \\
\text { (HU) }\end{array}$ & $\begin{array}{l}\mathrm{SHU}(\mathrm{HA} / \mu \mathrm{g} \\
\text { of protein) }\end{array}$ & $\begin{array}{l}\text { Purification } \\
\text { (fold) }\end{array}$ & Yield \% \\
\hline MKT Serum & 3 & 45 & 44.325 & 0.985 & 1 & 100 \\
\hline GalNAcBL & 7 & 0.0821 & 14.372 & 175.055 & 178 & 32.4 \\
\hline
\end{tabular}

MKT: Malignant Kidney Tumor Serum; GaINAcBL: N-Acetyl Galactosamine Binding Lectin

The analysis of PAGE electrophoresis pattern of purified lectins from patients with malignant kidney tumors is shown in Figure 4.

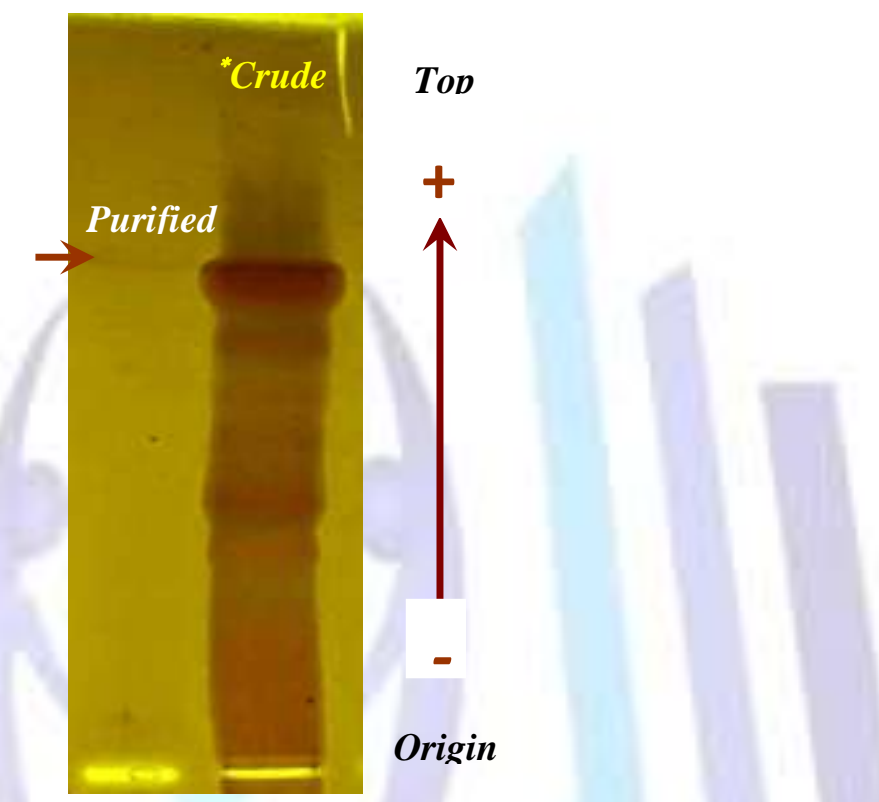

Fig 4: Conventional Ppolyacrylamide Gel Electrophoresis (PAGE) 7.5\% for Proteins. Tris - glycin buffer (0.075 $\mathrm{M}, \mathrm{pH}$ 8.9) used as the electrode buffer. Prelctrophoresis conditions were $50 \mathrm{~mA}$ as a constant current for 30 minutes, with voltage of $15 \mathrm{v} / \mathrm{cm}$, and at $4^{\circ} \mathrm{C}$. Electrophoresis was carried out for 10 minutes at $20 \mathrm{~mA}$, then the process was continued for 3.5 hours at $4^{\circ} \mathrm{C}$ by using $40 \mathrm{~mA}$ as a constant current and voltage of $15 \mathrm{v} / \mathrm{cm}$. The gel was stained for protein with silver stain.

The approximate molecular weights of purified GalNAcBL was determined using conventional PAGE. Five standard proteins with known molecular weighs (Lysozyme $13.6 \mathrm{kD}$, Chemotrypsinogene $25 \mathrm{kD}$, Ovalbumin $47 \mathrm{kD}$, Bovine Serum Albumin 67 kD, Lactate Dehydrogenase 140 kD)were used. The estimated molecular weight of GalNAcBL was 63.83.

GaINAcBL Activity toward Various Human Blood Groups: To examine the sensitivity of purified GalNAcBL in the agglutination reactions, blood of $\mathrm{A}^{+}, \mathrm{B}^{+}$, and $\mathrm{O}^{+}$groups were used as the source of the erythrocyte samples. $\mathrm{O}^{+} \mathrm{RBCs}$ were indicated to exhibit the maximal agglutination, among the evaluated blood groups, while the hemagglutination process of purified lectin (GalNAcBL) was failed. This finding could be explained by differences in glycosylation of the surface proteins of red blood cells [34]. Several studies tested the effect of blood sources on the hemagglutination process of purified lectins from various sources [35-37]; the result of the present study agreed with some and disagreed with the others.

Inhibition of GaINAcBL Activity by EDTA: The hemagglutination process was carried out for the purified GalNAcBL using human $\mathrm{O}^{+}$red blood cells trypsinized suspension in the presence of EDTA. GalNAcBL lost the hemagglutination activity, completely, in the presence of $1 \times 10^{-5} \mathrm{M}$ EDTA. This result clearly indicate that $\mathrm{Ca}^{2+}$ is crucial for the expression of the hemagglutination activity of GalNAcBL, thus; GalNAcBL should be classified as C-type lectin.

Relevance of GaINAcBL Activity with pH Changes: The effect of $\mathrm{pH}$ on the activity of the four purified GalNAcBL was investigated. Figure 5 points out that maximal lectin activity was achieved at pH 7.4 regardless to the source of the examined GalNAcBL, while the purified lectins were sensitive to acidic $(\mathrm{pH} 3)$ and to basic $(\mathrm{pH} 12)$ conditions, under which the activities were completely lost. 


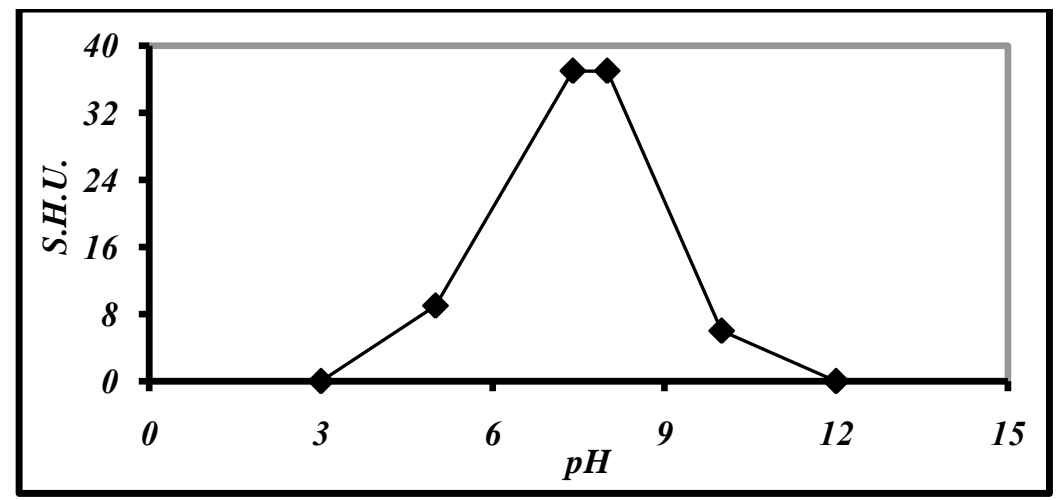

Fig 5: Effect of the $\mathrm{pH}$ on Purified GalNAcBL Hemagglutination Activity

Thermal Stability of GaINAcBL Activity:To explore the effect of temperature on the hemagglutination activity of purified GalNAcBL, it was incubated at various temperatures $\left(0^{\circ} \mathrm{C}, 30^{\circ} \mathrm{C}, 40^{\circ} \mathrm{C}, 50^{\circ} \mathrm{C}, 60^{\circ} \mathrm{C}, 80^{\circ} \mathrm{C}\right.$, and $\left.100^{\circ} \mathrm{C}\right)$ for 1 hour; the mixtures were cooled until room temperature. The hemagglutination activity was carried out at $30^{\circ} \mathrm{C}$ [37]. Thermal stability results revealed that purified lectins remained stable below $40^{\circ} \mathrm{C}$ for one hour with no loss of hemagglutination activity, while; they loss about $40 \%$ of their hemagglutination activity at $50{ }^{\circ} \mathrm{C}$. Lectin activity disappeared when the denaturation was carried out at more than $60^{\circ} \mathrm{C}$ (Figure 6).

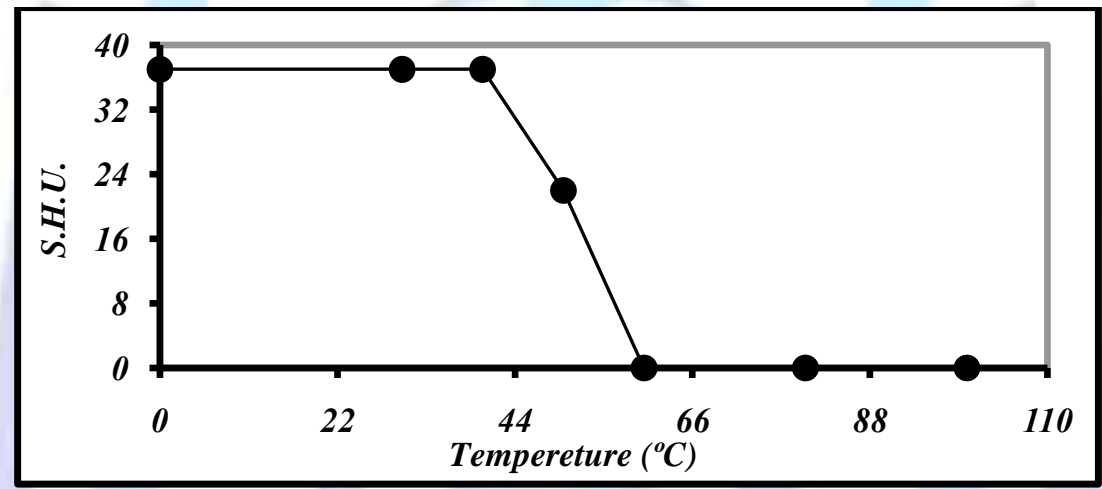

Fig 6: Thermal Denaturation of Purified GaINAcBL Hemagglutination Activity

The influence of temperature on the hemagglutination activity of purified GalNAcBL was also evaluated through the incubation of purified GalNAcBL with erythrocyte suspension at $0,32,37,45,60$, and $75^{\circ} \mathrm{C} .37^{\circ} \mathrm{C}$ seems to be more suitable among the examined temperatures for the agglutination process of purified GalNAcBL (Figure 7).

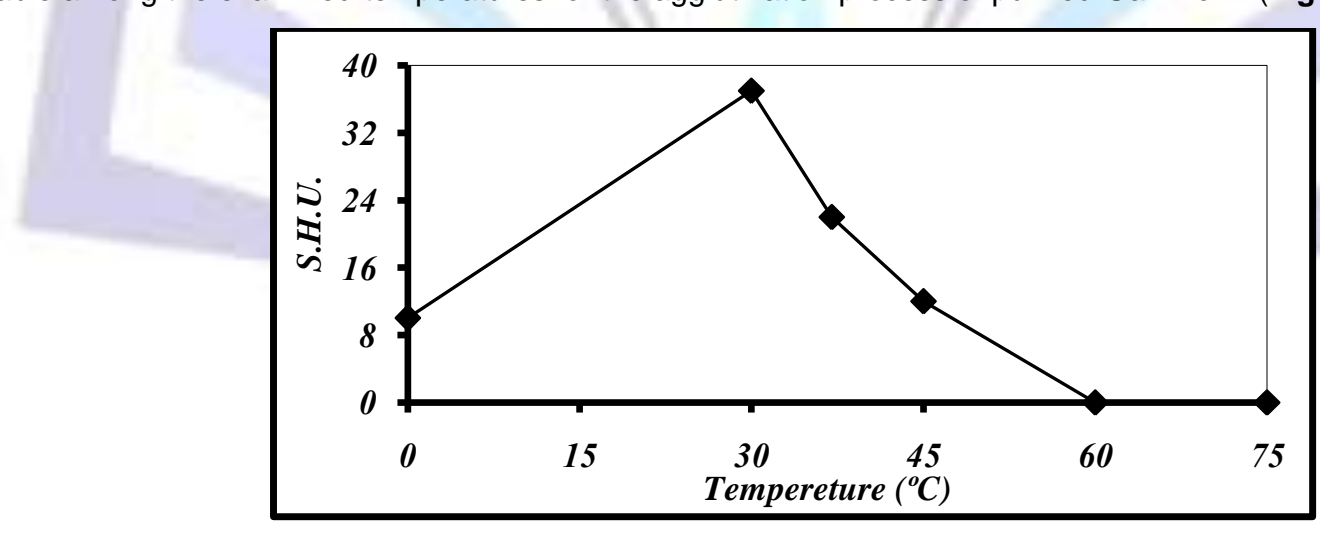

Fig 7: Temperature Effect on the Purified GalNAcBL Hemagglutination Activity

The Carbohydrate Content in Purified Lectins: Total carbohydrate content was found to be $8.7 \%$ from the purified GalNAcBL. 


\section{References}

(1) Vranken A M, Van Damme E J, Allen A K, \& Peumans W J. [1987]: Purification and properties of an Nacetylgalactosamine specific lectin from the plant pathogenic fungus Rhizoctonia solani. Federation of European Biochemical Societies J. Vol. 216, No. 1, p 67-72.

(2) Rapoport E M, Zhigis L S, Korchagina E Y, Ovachinnikova T V, Zubov V P, \& Bovin N V. [1996]: Isolation and characterization of galactose-binding lectins from human serum. Russian Bioorganic Chemistry J. Vol. 22, No. 55, p 353357.

(3) Kakiuchi M, Okino N, Sueyoshi N, Ichinose S, Omori A, Kawabata S, Yamaguchi K, \& Ito M. [2002]: Purification, characterization, and cDNA cloning of $\alpha-\mathrm{N}$ - acetylgalactosamine-specific lectin from starfish, Aserina pectifera. Glycobiology J. Vol. 12, No.2, p 85-94.

(4) Raymond R W. [2007]: Biochemistry of Cancer. In: Cancer Biology. Section 1.p 108-120.

(5) Pela'ez J \& Long J A. [2007]: Characterizing the glycocalyx of poultry spermatozoa: I. Identification and distribution of carbohydrate residues using flow cytometry and epifluorescence microscopy. Andrology J. Vol. 28, No. 2, p342-352.

(6) Kim J Y, Kim Y M, Cho S K, Choi K S, \& Cho M. [2008]: Noble tandem -repeat galectin of Manila clam Ruditapes philippinarum is induced upon infection with the protozoan parasite Perkinsus olseni. Developmental and Comparative Immunology J. Vol. 32, p 1131-1141.

(7) Rudenko N, Golovechenko M \& Grubhoffer L. [1999]: Lectin-like sequences in genome of Borrelia burgdorferi. Folia Parastiologica J. Vol. 46, p 81-90.

(8) Zampini M, Canesi L, Betti M, Ciacci C, Tarsi R, Gallo G, \& Pruzzo C. [2003]: Role for Mannose-Sensitive Hemagglutinin in Promoting Interactions between Vibrio cholerae El Tor and Mussel Hemolymph. Applied and Environmental Microbiology. Vol. 69, No. 9, p. 5711-5715.

(9) Opitz L, Salakang J, Büttner H, Reichl U, \& Wolff M W. [2007]: Lectin-affinity chromatography for downstream processing of MDCK cell culture derived human influenza A viruses. Vaccine. Vol. 25, p 939-947.

(10)Chandrasekaran A, Srinivasan1 A, Raman R, Viswanathan K, Raguram S,Tumpey T M, Sasisekharan V, \& Sasisekharan R. [2008]: Glycan topology determines human adaptation of avian H5N1 virus hemagglutinin. Nature Biotechnology J. Vol. 10, p 1-7.

(11)De Wolf F A \& Brett G M. [2000]: Ligand-Binding Proteins: Their Potential for Application in Systems for Controlled Delivery and Uptake of Ligands. Pharmacological Reviews. Vol. 52, No. 2, p 207-236.

(12)Pierini C. [2007]: Lectins: Their Damaging Role in Intestinal Health, Rheumatoid Arthritis and Weight Loss. Vitamin Research News J. Vol. 21, No. 1, p 1-4.

(13)Goldstein I J, Hughes R C, Monsigny M, Ozawa T, \& Sharon N. [1980]: What should be called a lectin? Nature J. Vol. 285, p 60-65.

(14)Brossmer R, Wagner M, \& Fischer E. [1992]: Specificity of the sialic acid-binding lectin from the snail Cepaea hortensis. Biol Chem. J. Vol. 267, p 8752-8756.

(15)Olivera S R, Nascimento AE, Lima M E, Leite Y F, \& Benevides N M. [2002]: Purification and characterization of a lectin from the red marine alga Pterocladiella capillacea (S.G. Gmel.) Santel. \& Hommers. Revista Brasil. Bot. J. Vol. 25, No. 4, p 397-403.

(16)Mayes P A \& Bender D A. [2006]: Overview of Metabolism. In: Murray R K, Granner D K, Mayes P A, \& Rodwell V W: Harper's Illustrated Biochemistry. Lange Medical Publications. $27^{\text {th }}$ Edition.

(17)Pine S R, Mechanic L E, Ambs S, Bowman E D , Chanock S J, Loffredo C, Shields P G, \& Harris C C. [2007]: Lung Cancer Survival and Functional Polymorphisms in MBL2, an Innate-Immunity Gene. J. Natl Cancer Inst, Vol. 99, p 14011409.

(18)Hans H. Wandall H H, Irazoqui F, Tarp M A, Bennett E P, Mandel U, Takeuchi H, Kato K, Irimura T, Suryanarayanan G, Hollingsworth M A, \& Clausen H. [2011]: The lectin domains of polypeptide GalNAc-transferases exhibit carbohydratebinding specificity for GalNAc: lectin binding to GalNAc-glycopeptide substrates is required for high density GalNAc-Oglycosylation. Glycobiology. Vol. 17 No. 4, p 374-387.

(19)Sutherlin M E, Nishimori I, Caffrey T, Bennett E P, Hassan H, Mandel U, \& Mack D. [1997]: Expression of three UDPNacetylalpha- D galactosamine:polypeptide GalNAc N-acetylgalactosaminyltransferases in adenocarcinoma cell lines. Cancer Res. Vol. 57, p 4744-4748.

(20)Mandel U,Hassan H, TherkildsenM H, Rygaard J, Jakobsen M H, Juh B R, \& Dabelsteen E. [1999]: Expression of polypeptide GalNActransferases in stratified epithelia and squamous cell carcinomas: immunohistological evaluation using monoclonal antibodies to three members of the GalNAc-transferase family. Glycobiology. Vol. 9, p 43-52. 
(21)Young W W, Holcomb D R, Ten Hagen K G, \& Tabak L A [2003]: Expression of UDP-GalNAc:polypeptide Nacetylgalactosaminyl transferase isoforms in murine tissues determined by real-time PCR: a new view of a large family. Glycobiology. Vol. 13, p 549-557.

(22)Shibao K, Izumi H, Nakayama Y, Ohta R, Nagata N, Nomoto M, \& Matsuo K. [2002]: Expression of UDP-N-acetyl-Dgalactosamine- polypeptide GalNAc-N-acetylgalactosaminyl transferase-3 in relation to differentiation and prognosis in patients with colorectal carcinoma. Cancer. Vol. 94, p1939-1946.

(23)Gu C, Oyama T, Osaki T, Li J, Takenoyama M, Izumi H, \& Sugio K. [2004]: Low expression of polypeptide GalNAc Nacetylgalactosaminyl transferase-3 in lung adenocarcinoma: impact on poor prognosis and early recurrence. Br $\mathrm{J}$ Cancer.Vol. 90, p436-442.

(24)Yamamoto S, Nakamori S, Tsujie M, Takahashi Y, Nagano H, Dono K, \& Umeshita K. [2004]: Expression of uridine diphosphate $\mathrm{N}$-acetyl-alpha-D galactosamine: polypeptide $\mathrm{N}$-acetylgalactosaminyl transferase 3 in adenocarcinoma of the pancreas. Pathobiology. Vol. 71, p 12-18.

(25)Ishikawa M, Kitayama J, Nariko H, Kohno K, \& Nagawa H. [2004]: The expression pattern of UDP-N-acetyl-alpha-Dgalactosamine: polypeptide $\mathrm{N}$-acetylgalactosaminyl transferase-3 in early gastric carcinoma. J Surg Oncol. Vol. 86, p 2833.

(26)Miyahara N, Shoda J, Kawamoto T, Furukawa M, Ueda T, Todoroki T, \& Tanaka N. [2004]: Expression of UDP-Nacetyl-alpha-Dgalactosamine- polypeptide $\mathrm{N}$-acetylgalactosaminyltransferase isozyme 3 in the subserosal layer correlates with postsurgical survival of pathological tumor stage 2 carcinoma of the gallbladder. Clin Cancer Res. Vol. 10, p 20902099.

(27)Landers K A, Burger MJ, Tebay M A, Purdie D M, Scells B, Samaratunga H, \& Lavin M F. [2005]: Use of multiple biomarkers for a molecular diagnosis of prostate cancer. Int J Cancer. Vol. 114, p 950-956.

(28)Berois N, Mazal D, Ubillos L, Trajtenberg F, Andre' Nicolas, Sastre-Garau X, Magdelenat H, \& Osinaga E. [2006]: UDP-N-Acetyl-D-Galactosamine: Polypeptide N-Acetylgalactosaminyltransferase-6 as a New Immunohistochemical Breast Cancer Marker. Journal of Histochemistry \& Cytochemistry. Vol. 54, No. 3, p 317-328.

(29)Bradford M. [1976]: A rapid and sensitive method for the quantitation of microgram quantities of proteins utilizing the principle of protein-dye binding. Anal. Biochem. J. Vol. 72, p 248-254.

(30)Lis H \& Sharon N. [1987]: Lectins as molecules and as tools. Ann. Rev. Biochem. Vol. 55, p 35-67.

(31)Hermanson G T, Mallia A K, \& Smith P K. [1992]: Immobilized Affinity Ligand Techniques. UK. Academic Press, Inc.

(32)Dubois M, Gilles K A, Hamilton J K, Robers P A and Smith, F. [1956]: Colorimetric method for determination of sugars, and related substances. Annal. Biochem. Vol. 28, No. 3, p350-356.

(33) Iurisci I, Tinari N, Natoli C, Angelucci D, Cianchetti E, \& lacobelli S. [2000]: Concentrations of Galectin-3 in the Sera of Normal Controls and Cancer Patients. Clinical Cancer Research. Vol. 6, p 1389-1393.

(34)Percival R S, Marsh P D, Devine D A, Rangarajan M, Aduse J, Shepherd P, Curtis M A. [1999]: Effect of Temperature on Growth, Hemagglutination, and Protease Activity of Porphyromonas gingivalis. Infection and Immunity. Vol. 67, No. 4, p 1917-1921.

(35)Sarray S, Berthet V, Calvete J J, Jeannine Secchi J, Marvaldi J, El Ayeb1 M, Marrakchi N, \& Luis J. [2004]: Lebectin, a novel C-type lectin from Macrovipera lebetina venom, inhibits integrinmediated adhesion, migration and invasion of human tumor cells. Laboratory Investigation J. Vol. 84, p 573-581.

(36)Al-Sohaimy S A, Hafez E E, Abdelwahab A E, \& El-Saadani A E. [2007]: Anti -HCV Lectin from Egyptian Pisum sativum. Australian Basic and Applied Sciences J. Vol. 1, No. 3, p 213-219.

(37)Rasha H J, Hathama R H, and Majid K H. [2009]: Detection of malignant human kidney lectins and study of their optimum hemagglutination conditions. The Proceeding of the Third Scientific Conference of College of Science, Baghdad University. p1563-1577. 